\title{
INDIKATOR KUALITAS AUDIT: PERSEPSI AUDITOR MUSLIM
}

\author{
Etika Rosy, M. Asmeldi Firman dan Ahmad Tarmizi Lubis \\ Sekolah Tinggi Ekonomi Islam SEBI \\ Email : etikarosy86@gmail.com,masmeldif@gmail.com dan atarmizilubis@gmail.com
}

\begin{abstract}
This research aims to examine indicators that affect audit quality according to Muslim auditors. The object of this research is the Public Accounting Firm (KAP) in Jakarta and Depok. The data collection technique used questionnaire model with random sampling technique of auditors from $11 \mathrm{KAP}$. The research method is quantitative research and the data analysis tool used Structural Equation Modeling (SEM) approach to Partial Least Square (PLS). The results of this study indicate that integrity has a significant effect on audit quality, while the caliph \& sincerity, piety \& fear of Allah SWT, truth and working perfectly and responsibly to Allah SWT does not affect audit quality.
\end{abstract}

Keywords: Audit Quality, Codes of Ethics, Muslim Auditor

\section{PENDAHULUAN}

Profesi akuntan publik adalah profesi yang bertanggung jawab untuk menaikkan tingkat keandalan laporan keuangan. Salah satu jasa akuntan publik adalah memberikan informasi yang akurat dan dapat dipercaya untuk pengambilan keputusan bagi para pengguna. Profesi akuntan publik merupakan profesi kepercayaan masyarakat, dimana masyarakat mengharapkan penilaian yang bebas dan tidak memihak terhadap informasi yang disajikan oleh manajemen perusahaan dalam laporan keuangan (Mulyadi, 2002)

Kantor Akuntan Publik (KAP) dalam memberikan layanan jasa audit yang berkualitas tinggi, belum optimal dalam memenuhi harapan pengguna jasa. Berbagai kecurangan masih sering terjadi yang melibatkan praktisi akuntan publik. Hal ini tentunya akan berakibat pada keraguan jasa audit akan integritas Akuntan Publik. Pada akhir-akhir ini kualitas yang dihasilkan akuntan publik kembali mendapat sorotan oleh masyarakat terkait banyak kasus yang melibatkan auditor independen.

Terungkapnya berbagai kasus kecurangan laporan keuangan dimulai dari peristiwa runtuhnya salah satu perusahaan raksasa di Amerika Serikat yaitu Enron Corporation pada tahun 2001. Kecurangan yang dilakukan Enron melibatkan Kantor Akuntan Publik (KAP) international Arthur Anderson (AA). Independensi Auditor merupakan salah satu faktor yang diduga memicu masalah Enron. AA telah melakukan tugas pengauditan keuangan Enron hampir selama 20 tahun. Seharusnya AA banyak mengetahui masalah yang dihadapi oleh kliennya, Enron (Khairunisa \& Hanny Yustrianthe, 2015). 
Mengapa KAP sebesar AA tidak mampu mengungkapkan permasalahan di dalam organisasi Enron dan secara sadar ikut terlibat dalam suatu konspirasi oleh Enron? Arthur Andersen didakwa bersalah atas tuduhan menghalang keadilan dengan memusnahkan ribuan dokumen serta mematikan email milik Enron yang diperlukan untuk tujuan audit. Diketahui pula bahwa Enron telah melakukan kecurangan laporan keuangan selama 4 tahun. Banyak pihak menempatkan auditor sebagai pihak yang paling bertanggung jawab terhadap masalah ini.

Di Indonesia, saat ini muncul kasus terbaru mengenai AP Marlina dan AP Merliyana Syamsul dari KAP Satrio, Bing, Eny (KAP SBE) yang merupakan entitas dari Deloitte Indonesia telah memberikan opini Wajar Tanpa Pengecualian (WTP) kepada PT Sunprima Nusantara Pembiayaan (SNP Finance). Selanjutnya hasil audit digunakan SNP Finance untuk mendapatkan kredit dari perbankan dan menerbitkan utang jangka menengah atau Medium Term Note (MTN). Berdasarkan hasil pemeriksaan OJK, SNP Finance terindikasi telah menyajikan laporan keuangan yang tidak sesuai dengan kondisi keuangan perusahaan sebenarnya, sehingga menyebabkan kerugian banyak pihak dikarenakan kredit MTN SNP Finance yang berpotensi mengalami gagal bayar atau kredit bermasalah (Prabowo, 2018)

OJK menilai, AP Marlina dan AP Merliyana Syamsul telah melanggar POJK Nomor 13/POJK.03/2017 Tentang Penggunaan Jasa Akuntan Publik dan Kantor Akuntan Publik. Beberapa pelanggaran yang dilakukan antara lain, memberikan opini yang tidak mencerminkan kondisi perusahan yang sebenarnya. Imbasnya, industri jasa keuangan dan masyarakat menanggung kerugian besar atas opini kedua AP tersebut terhadap laporan keuangan SNP Finance.

Selain keterlibatan kecurangan yang dilakukan oleh KAP Big Four, KAP non Big Four di Indonesia juga mengalami kegagalan audit, salah satunya kasus yang terjadi pada perusahaan Raden Motor. KAP Biasa Sitepu diduga kuat terlibat dalam kasus korupsi pada kredit macet. Berdasarkan hasil pemeriksaan dan konfrontir keterangan tersangka dengan saksi Biasa Sitepu terungkap ada kesalahan dalam laporan keuangan perusahaan Raden Motor dalam mengajukan pinjaman ke BRI. Ada 4 kegiatan data laporan keuangan yang tidak dibuat oleh akuntan publik, sehingga terjadilah kesalahan dalam proses kredit dan ditemukan dugaan korupsinya (Kompas, 2010). Dalam kasus ini KAP Biasa Sitepu dibekukan izin praktek auditnya selama 2 tahun terhitung tanggal 7 Juli 2012 oleh Menteri Keuangan.

Banyaknya kasus terkait profesi audit menunjukkan bahwa terjadi kemerosotan moral dari seorang akuntan publik. Kurangnya kesadaran akan etika profesi yang digelutinya semakin memperparah keadaan. Citra sebuah profesi ternoda karena perbuatan beberapa orang. Akuntan publik bahkan dituduh sebagai pihak yang paling besar tanggung jawabnya atas kemerosotan perekonomian Indonesia (Ludigdo, 2006). Kegagalan ini selain merugikan kantor Akuntan Publik secara ekonomis, juga menyebabkan hilangnya reputasi Akuntan Publik di mata masyarakat dan hilangnya kepercayaan kreditor dan investor di pasar modal (Noviyanti, 2008) . 
Di Indonesia yang mayoritas penduduknya muslim, kode etik sangatlah di perlukan terutama kode etik syariah. Sebuah pertanyaan muncul apakah kode etik syariah harus diterapkan di profesi Akuntan Publik mengingat besarnya tanggung jawab yang diemban oleh seorang Akuntan Publik? Seperti yang kita ketahui seorang auditor muslim memiliki ketakutan terhadap Allah baik dalam keadaan tersembunyi maupun terang-terangan. Jadi, kemungkinan seorang auditor muslim melakukan manipulasi laporan keuangan itu sangtatlah kecil.

Realitas sosial yang terjadi saat ini menggambarkan bahwa etika profesi seakan terabaikan. Banyaknya kasus-kasus terkait profesi audit menunjukkan bahwa terjadi degradasi moral dari seorang Auditor. Kurangnya kesadaran akan etika profesi yang digelutinya semakin memperparah keadaan. Seperti contoh kasus yang terjadai pada KAP Arthur Anderson, KAP Biasa Sitepu dan yang terakhir KAP Deloitte. Citra sebuah profesi audit seakan yang mulai pudar ternoda karena perbuatan-perbuatan yang melanggar etika profesi oleh praktik segelintir orang.

Seorang auditor harus memiliki pemahaman dan kesadaran profesinya, lebih lagi apabila ia adalah seorang auditor muslim. Di Indonesia seorang auditor harus patuh pada etika profesi yang berlaku secara umum yaitu Standar Profesional Akuntan Publik (SPAP). Untuk melihat sisi-sisi kemusliman dari auditor muslim, auditor harus melihat indikator kode etik akuntan yang terdapat pada AAOIFI, tanpa mengesampingkan etika profesi pada SPAP. Etika-etika tersebut jika dikombinasikan akan memunculkan beberapa variabel yang menjadi ukuran yaitu : (1) integritas, (2) khalifah dan ikhlas, (3) ketakwaan dan takut pada Allah SWT, (4) kebenaran dan bekerja secara sempurna, (5) manusia bertanggung jawab dihadapan Allah SWT.

\section{LANDASAN TEORI}

\subsection{TEORI ATRIBUSI}

Menurut Fritz Heider, teori atribusi merupakan teori yang menjelaskan tentang perilaku seseorang. Teori atribusi menjelaskan mengenai proses bagaimana kita menentukan penyebab dan motif tentang perilaku seseorang. Teori ini mengacu tentang bagaimana seseorang menjelaskan penyebab perilaku orang lain atau dirinya sendiri yang akan ditentukan apakah dari internal misalnya sifat, karakter, sikap, dll ataupun eksternal misalnya tekanan situasi atau keadaan tertentu yang akan memberikan pengaruh terhadap perilaku individu (Luthans, 2005).

Dalam penelitian ini, peneliti menggunakan teori atribusi karena peneliti akan melakukan studi empiris untuk mengetahui faktor-faktor yang mempengaruhi auditor terhadap kualitas hasil audit, khususnya pada karakteristik personal auditor itu sendiri. Pada dasarnya karakteristik personal seorang auditor merupakan salah satu penentu terhadap kualitas hasil audit yang akan dilakukan karena merupakan suatu factor internal yang mendorong seseorang untuk melakukan suatu aktivitas. 


\subsection{AUDIT}

Audit merupakan kegiatan pemeriksaan dan pengujian suatu pernyataan, pelaksanaan dari kegiatan yang dilakukan oleh pihak independen guna memberikan suatu pendapat. Pihak yang melaksanakan audit disebut dengan auditor. Pengertian audit semakin berkembang sesuai dengan kebutuhan yang meningkat akan hasil pelaksanaan audit. Menurut (Agoes, 2017) pengertian audit adalah :

"Audit adalah suatu pemeriksaan yang dilakukan secara kritis dan sistematis, oleh pihak yang independen, terhadap laporan keuangan yang telah disusun oleh manajemen, beserta catatan-catatan pembukuan dan bukti-bukti pendukungnya, dengan tujuan untuk dapat memberikan pendapat mengenai kewajaran laporan keuangan tersebut".

\subsection{KUALITAS AUDIT}

The International Auditing and Assurance Standards Boards (IAASB) telah membangun sebuah kerangka untuk kualitas audit. Kerangka tersebut terdiri atas unsur-unsur berikut ini: (1) input, (2) proses, (3) Output. Dengan membangun sebuah kerangka audit, IAASB memiliki tujuan untuk meningkatkan kesadaran terhadap elemen kunci dari kualitas audit dilingkungan mereka serta memfasilitasi dialog yang lebih besar antara stakeholder terhadap topik terkait.

\subsection{PROFESI AKUNTAN PUBLIK}

Akuntan publik adalah seseorang yang telah memperoleh izin untuk memberikan jasa-jasa sebagaimana diatur dalam undang-undang. Berdasarkan undang-undang, Akuntan Publik memberikan jasa assurance, yang meliputi : a) jasa audit atas informasi keuangan historis, b) jasa review atas informasi keuangan historis dan, c) jasa asurans lainnya. Jasa assurance ini hanya dapat diberikan oleh Akuntan Publik. Selain jasa asurans, Akuntan Publik dapat memberikan jasa lainnya yang berkaitan dengan akuntansi, keuagan, dan manajemen sesuai dengan ketentuan peraturan perundangundangan (Tuanakotta, 2017).

\subsection{KODE ETIK PROFESI}

Kode etik profesi merupakan kriteria prinsip profesional yang telah digariskan, sehingga diketahui dengan pasti kewajiban profesional anggota lama, baru ataupun calon anggota kelompok profesi. Kode etik profesi telah menentukan standarisasi kewajiban profesional anggota kelompok profesi. Maka pemerintah atau masyarakat tidak perlu campur tangan untuk menentukan bagaimana profesional menjalankan kewajibannya.

Kode etik yang digunakan Akuntan Publik di Indonesia adalah kode etik yang terdapat dalam Standar Profesional Akuntan Publik (SPAP) . Terdapat lima Kode Etik dalam SPAP yaitu : (1) integritas, (2) objektivitas, (3) kompetensi serta sikap kecermatan dan kehati-hatian, (4) prinsip kerahasiaan, (5) prisip perilaku profesional. Dalam Kode Etik Akuntan 
Indonesia disebutkan bahwa tujuan profesi akuntansi adalah memenuhi tanggung jawabnya dengan standar profesionalisme tertinggi, mencapai tingkat kinerja tertinggi dengan orientasi kepada kepentingan publik.

Selain kode etik yang terdapat dalam SPAP, AAOFI juga memiliki kode etik yang secara khusus mengatur seorang akuntan muslim. Kode Etik Akuntan Muslim yang terdapat dalam AAOIFI adalah : (1) integritas, (2) khalifah dan ikhlas, (3) ketakwaan, (4) kebenaran dan bekerja sempurna, (5) takut kepada Allah. Landasan-landasan etika profesi akuntan publik yang ditetapkan oleh AAOIFI memiliki keterkaitan dengan kode etik akuntan publik yang sudah ditetapkan oleh IAPI dalam SPAP karena landasanlandasan tersebut merupakan bentuk sifat-sifat terpuji yang harus dijiwai dan diaplikasikan oleh para akuntan publik. (Masluhih, Masyhad, \& Hidayati, 2016).

\section{METODE PENELITIAN}

Jenis penelitian yang digunakan dalam penelitian ini adalah jenis penelitian kuantitatif. Metode penelitian kuantitatif digunakan untuk meneliti pada populasi atau sampel tertentu, pengumpulan data menggunakan instrument penelitian dan analisis data bersifat kuantitatif/statistik (Apriliyanto,2015).

Populasi dalam penelitian ini adalah seluruh akuntan publik atau auditor yang terdaftar dan bekerja pada Kantor Akuntan Publik (KAP) yang ada di Depok dan Jakarta. Dalam penelitian ini, penulis menggunakan metode probability sampling, yaitu teknik pengambilan sampel yang memberikan peluang yang sama bagi setiap unsur (anggota) populasi untuk dipilih menjadi anggota sampel. Teknik sampling yang digunakan dalam penelitian ini adalah simple random sampling di mana pengambilan sampel dilakukan secara acak tanpa memperhatikan strata yang ada dalam populasi tersebut (Sugiyono, 2010).

Teknik analisis data dalam penelitian ini dilakukan dengan model SEM (Structural Equation Modeling) dengan pendekatan PLS (Partial Least Square), dimana model ini merupakan kumpulan teknik statistik yang memungkinkan dilakukanya pengujian terhadap serangkaian hubungan yang relative rumit dan simultan. Penelitian ini menggunakan model SEM karena penelitian ini bertujuan untuk melihat hubungan antar variabel dimana variabel-variabel dalam penelitian tidak dapat diukur secara langsung, tetapi memerlukan indikator sebagai alat ukur.

\section{HASIL PENELITIAN DAN PEMBAHASAN}

\subsection{EVALUASI MODEL PENGUKURAN (OUTER MODEL)}

1. Evaluasi Convergent Validity 


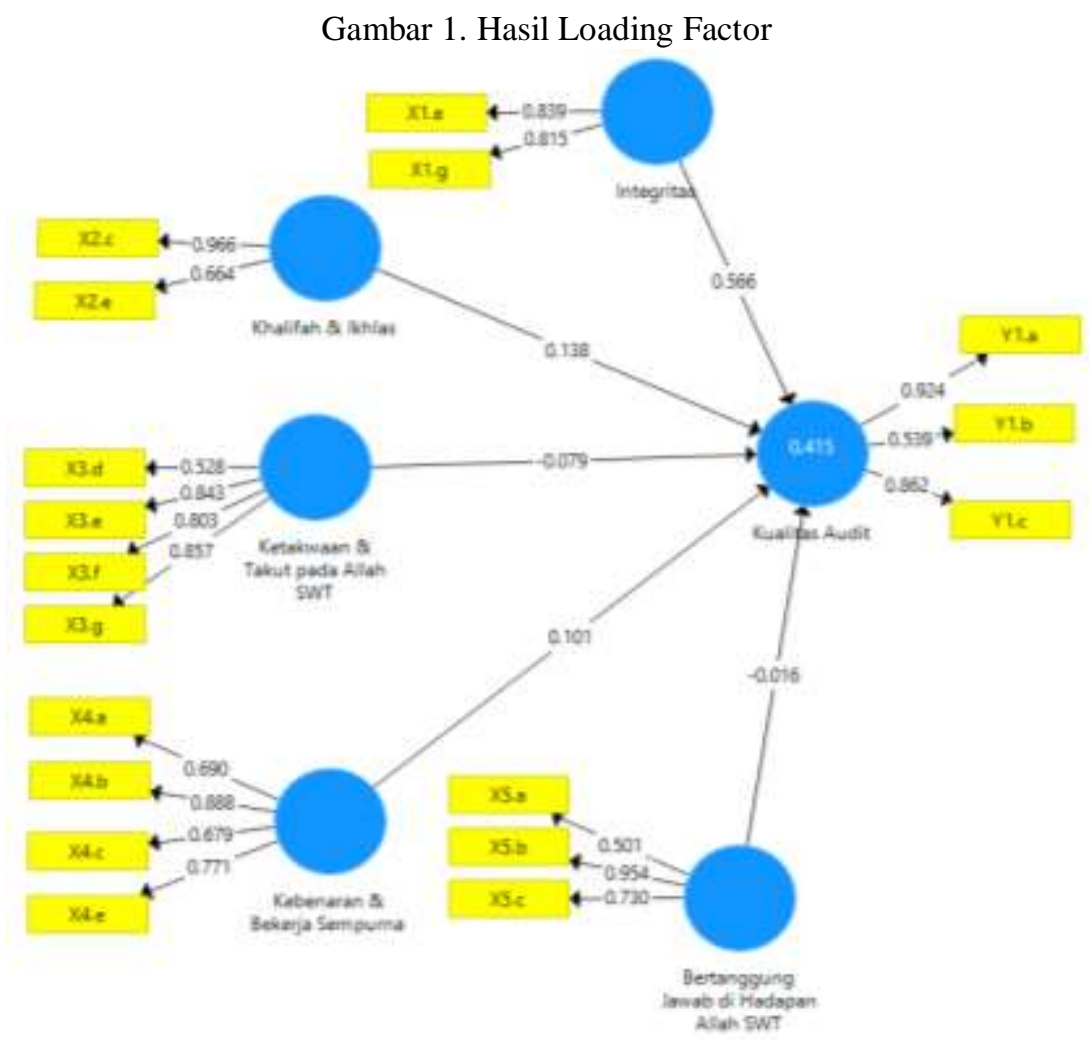

Sumber: Data diolah menggunakan SmartPLS, 2019

Pada gambar 1 menghasilkan nilai loading factor pada semua indikator diatas 0,5 . Hasil tersebut bermakna bahwa hasil pengujian variabel $\mathrm{X}$ dengan semua indikator tetap bisa menjelaskan variabel $\mathrm{X}$ nya, sedangkan pengujian ulang untuk variabel $\mathrm{Y}$ hanya tertinggal dua indikator yang dianggap mampu me njelaskan variabel Y. Hasil akhir inilah yang dijadikan dasar untuk melakukan pengujian selanjutnya.

Tabel 1. Hasil Uji Internal Consistency Reliability

\begin{tabular}{lcccc}
\hline \multicolumn{1}{c}{ Variabel } & $\begin{array}{c}\text { Cronbach's } \\
\text { Alpha }\end{array}$ & rho_A & $\begin{array}{c}\text { Composite } \\
\text { Reliability }\end{array}$ & AVE \\
\hline Integritas & 0,538 & 0,539 & 0,812 & 0,684 \\
\hline Khalifah dan Ikhlas & 0,619 & 1.137 & 0,809 & 0,687 \\
\hline $\begin{array}{l}\text { Ketakwaan dan Takut } \\
\text { pada Allah SWT }\end{array}$ & 0,766 & 0,820 & 0,850 & 0,593 \\
\hline $\begin{array}{l}\text { Kebenaran dan Bekerja } \\
\text { secara Sempurna }\end{array}$ & 0,797 & 0,909 & 0,845 & 0,581 \\
\hline Bertanggung Jawab di & 0,659 & 1.237 & 0,785 & 0,565 \\
\hline
\end{tabular}




\begin{tabular}{lcccc}
\hline \multicolumn{1}{c}{ Variabel } & $\begin{array}{c}\text { Cronbach's } \\
\text { Alpha }\end{array}$ & rho_A & $\begin{array}{l}\text { Composite } \\
\text { Reliability }\end{array}$ & AVE \\
\hline Hadapan Allah SWT & 0,698 & 0,824 & 0,829 & 0,629 \\
\hline Kualitas Audit & Sumber: Data diolah menggunakan SmartPLS, 2019
\end{tabular}

Hasil pengujian berdasarkan tabel 4.1 menunjukkan nilai composite reliability dari masing-masing variabel yakni integritas sebesar 0,812; khalifah dan ikhlas sebesar 0,809; ketakwaan dan takut pada Allah SWT sebesar 0,850; kebenaran dan bekerja secara sempurna sebesar 0,845; bertanggung jawab dihadapan Allah SWT sebesar 0,785; dan kualitas audit sebesar 0,829. Hasil tersebut menunjukkan bahwa nilai dari masing-masing konstrak diatas 0,7 sehingga semua konstrak dapat dinyatakan valid.

Pemeriksaan terakhir untuk melihat convergent validity baik atau tidak adalah dengan melihat output AVE. AVE digunakan untuk mengukur banyaknya varians yang dapat ditangkap oleh variabelnya dibandingkan dengan variansi yang ditimbulkan oleh kesalahan pengukuran. variabel memiliki convergent validity yang baik apabila nilai AVE lebih dari 0,5 (Yamin \& Kurniawan, 2011). Pada tabel 4.11 nilai AVE untuk semua variabel > 0,5 dengan nilai AVE dari masing-masing konstrak yakni integritas sebesar 0,684; khalifah dan ikhlas sebesar 0,687; ketakwaan dan takut pada Allah SWT sebesar 0,593; kebenaran dan bekerja secara sempurna sebesar 0,581; bertanggung jawab di hadapan Allah SWT sebesar 0,565; dan kualitas audit sebesar 0,629. Dengan demikian, dapat ditarik kesimpulan bahwa hasil akhir masing-masing indikator mampu menjelaskan variabelnya, sehingga variabel ini mampu menjelaskan masalah yang sedang diteliti.

\section{Evaluasi Discriminant Validity}

Discriminant validity dari model reflektif dievaluasi melalui cross loading dan nilai AVE kuadrat dengan nilai korelasi antar variabel. Hasil dari cross loading, apabila korelasi antar indikator dengan variabelnya lebih tinggi dari korelasi dengan variabel lainnya, hal ini menunjukkan variabel tersebut memprediksi ukuran pada blok mereka dengan lebih baik dari blok lainnya (Yamin \& Kurniawan, 2011). Berikut ini cross loading yang dihasilkan pada penelitian ini :

Tabel 2. Hasil Evaluasi Discriminant Validity melalui Cross Loading

\begin{tabular}{ccccccc}
\hline & X1 & X2 & X3 & X4 & X5 & Y \\
\hline X1.e & 0,839 & 0,358 & 0,557 & 0,578 & 0,144 & 0,536 \\
\hline X1.g & 0,815 & 0,248 & 0,374 & 0,403 & 0,258 & 0,503 \\
\hline X2.c & 0,353 & 0,966 & 0,380 & 0,164 & 0,348 & 0,359 \\
\hline X2.e & 0,254 & 0,664 & 0,183 & 0,338 & 0,168 & 0,124 \\
\hline X3.d & 0,368 & 0,041 & 0,528 & 0,502 & 0,325 & 0,142 \\
\hline X3.e & 0,422 & 0,280 & 0,843 & 0,393 & 0,387 & 0,308 \\
\hline
\end{tabular}




\begin{tabular}{ccccccc}
\hline & $\mathrm{X} 1$ & $\mathrm{X} 2$ & $\mathrm{X} 3$ & $\mathrm{X} 4$ & $\mathrm{X} 5$ & $\mathrm{Y}$ \\
\hline $\mathrm{X} 3 . \mathrm{f}$ & 0,514 & 0,262 & 0,803 & 0,527 & 0,192 & 0,262 \\
\hline $\mathrm{X} 3 . \mathrm{g}$ & 0,461 & 0,449 & 0,857 & 0,489 & 0,460 & 0,313 \\
\hline X4.a & 0,255 & 0,150 & 0,449 & 0,690 & 0,264 & 0,135 \\
\hline X4.b & 0,546 & 0,144 & 0,411 & 0,888 & 0,271 & 0,453 \\
\hline X4.c & 0,249 & 0,076 & 0,469 & 0,679 & 0,178 & 0,103 \\
\hline X4.e & 0,549 & 0,299 & 0,580 & 0,771 & 0,190 & 0,333 \\
\hline X5.a & 0,174 & 0,254 & 0,341 & 0,149 & 0,501 & 0,042 \\
\hline X5.b & 0,206 & 0,323 & 0,431 & 0,277 & 0,954 & 0,182 \\
\hline X5.c & 0,208 & 0,196 & 0,217 & 0,217 & 0,730 & 0,065 \\
\hline Y1.a & 0,645 & 0,323 & 0,358 & 0,409 & 0,140 & 0,924 \\
\hline Y1.b & 0,240 & 0,098 & 0,045 & 0,299 & 0,064 & 0,539 \\
\hline Y1.c & 0,514 & 317 & 0,324 & 0,296 & 0,163 & 0,862 \\
\hline
\end{tabular}

Sumber: Data diolah menggunakan SmartPLS, 2019

Tabel 2 menunjukkan bahwa nilai cross loading dari masing-masing indikator terhadap variabelnya lebih besar daripada nilai cross loading dari indikator lainnya. Hal ini menunjukkan bahwa konstrak berkorelasi lebih tinggi dengan masing-masing variabelnya sehingga dapat dinyatakan memiliki discriminant validity yang baik.

Evaluasi selanjutnya adalah membandingkan nilai akar AVE dengan korelasi dan konstrak. Ukuran discriminant validity dinyatakan baik apabila nilai akar AVE lebih tinggi daripada korelasi antara konstrak dengan konstrak lainnya.

Tabel berikut ini menunjukkan hasil akar AVE :

Tabel 3. Hasil Akar AVE

\begin{tabular}{lcc}
\hline \multicolumn{1}{c}{ Variabel } & AVE & Akar AVE \\
\hline Integritas & 0,684 & 0,827 \\
\hline Khalifah dan Ikhlas & 0,687 & 0,828 \\
\hline Ketakwaan dan Takut Pada Allah SWT & 0,593 & 0,770 \\
\hline Kebenaran dan Bekerja Secara Sempurna & 0,581 & 0,762 \\
\hline Bertanggung Jawab di Hadapan Allah SWT & 0,565 & 0,751 \\
\hline Kualitas Audit & 0,629 & 0,793 \\
\hline
\end{tabular}

Sumber: Data diolah menggunakan SmartPLS, 2019

Dari tabel 3. diatas dapat diketahui bahwa akar AVE untuk variabel integritas sebesar 0,827; akar AVE untuk variabel khalifah dan ikhlas sebesar 0,828; akar AVE untuk variabel ketakwaan dan takut pada Allah SWT sebesar 0,770; akar AVE kebenaran dan bekerja secara sempurna sebesar 
0,762; akar AVE bertanggung jawab di hadapan Allah SWT sebesar 0,751 akar AVE kualitas audit sebesar 0,793. Adapun nilai dari korelasi antar variabel latennya adalah sebagai berikut :

Tabel 4. Laten Variabel Correlations

\begin{tabular}{|c|c|c|c|c|c|c|}
\hline & $\mathrm{X} 1$ & $\mathrm{X} 2$ & X3 & $\mathrm{X} 4$ & $\mathrm{X} 5$ & $\mathrm{Y}$ \\
\hline $\mathrm{X} 1$ & 1 & & & & & \\
\hline $\mathrm{X} 2$ & 0,369 & 1 & & & & \\
\hline X3 & 0,567 & 0,371 & 1 & & & \\
\hline $\mathrm{X} 4$ & 0,596 & 0,235 & 0,594 & 1 & & \\
\hline X5 & 0,240 & 0,340 & 0,442 & 0,292 & 1 & \\
\hline $\mathrm{Y}$ & 0,629 & 0,336 & 0,346 & 0,419 & 0,162 & 1 \\
\hline
\end{tabular}

Tabel 1. Hail Korelasi Dengan Variabel Laten

\begin{tabular}{cccccccccc}
\hline & & \multicolumn{7}{c}{ Hasil Korelasi Dengan Variabel Laten } & $\begin{array}{c}\text { Kesim } \\
\text { pulan }\end{array}$ \\
\cline { 3 - 9 } bel & Akar & AVE & X1 & X2 & X3 & X4 & X5 & Y & $\begin{array}{c}>\text { atau } \\
<\end{array}$ \\
\hline X1 & 0,827 & 1 & 0,369 & 0,567 & 0,596 & 0,240 & 0,629 & $>$ \\
\hline X2 & 0,828 & 0,369 & 1 & 0,371 & 0,235 & 0,340 & 0,336 & $>$ \\
\hline X3 & 0,770 & 0,567 & 0,371 & 1 & 0,594 & 0,442 & 0,346 & $>$ \\
\hline X4 & 0,762 & 0,596 & 0,235 & 0,594 & 1 & 0,292 & 0,419 & $>$ \\
\hline X5 & 0,751 & 0,240 & 0,340 & 0,442 & 0,292 & 1 & 0,162 & $>$ \\
\hline Y & 0,793 & 0,629 & 0,336 & 0,346 & 0,419 & 0,162 & 1 & $>$ \\
\hline
\end{tabular}

Sumber: Data diolah menggunakan SmartPLS, 2019

Berdasarkan tabel 5 diatas diketahui bahwa secara umum akar AVE memiliki nilai lebih tinggi dari korelasi antar variabel laten. Bersasarkan hasil perbandingan antara akar AVE dengan korelasi antara variabel, disimpulkan bahwa discriminat validity nya dinyatakan baik.

4.2 EVALUASI MODEL STRUKTURAL (INNER MODEL)

Tabel 2. Hasil Path Coefficient

\begin{tabular}{lccccc}
\hline & $\begin{array}{c}\text { Original } \\
\text { Sampel }\end{array}$ & $\begin{array}{c}\text { Sample } \\
\text { Mean }\end{array}$ & $\begin{array}{c}\text { Standard } \\
\text { Deviation }\end{array}$ & $\begin{array}{c}\text { T- } \\
\text { Stati } \\
\text { stic }\end{array}$ & $\begin{array}{c}\text { Value } \\
\text { s }\end{array}$ \\
\hline Integritas -> Kualitas Audit & 0,566 & 0,558 & 0,149 & 3.803 & 0,000 \\
\hline $\begin{array}{l}\text { Khalifah dan Ikhals -> } \\
\text { Kualitas Audit }\end{array}$ & 0,138 & 0,131 & 0,162 & 0,855 & 0,393 \\
\hline Ketakwaan dan Takut Pada & $-0,079$ & $-0,093$ & 0,214 & 0,369 & 0,712 \\
\hline
\end{tabular}




\begin{tabular}{lccccc}
\hline & $\begin{array}{c}\text { Original } \\
\text { Sampel }\end{array}$ & $\begin{array}{c}\text { Sample } \\
\text { Mean }\end{array}$ & $\begin{array}{c}\text { Standard } \\
\text { Deviation }\end{array}$ & $\begin{array}{c}\text { T- } \\
\text { Stati } \\
\text { stic }\end{array}$ & $\begin{array}{c}\text { Value } \\
\text { S }\end{array}$ \\
\hline Allah SWT -> Kualitas Audit & & & & & \\
\hline $\begin{array}{l}\text { Kebenaran dan Bekerja } \\
\text { Secara Sempurna -> Kualitas } \\
\text { Audit }\end{array}$ & 0,101 & 0,178 & 0,204 & 0,494 & 0,622 \\
\hline $\begin{array}{l}\text { Bertanggung Jawab di } \\
\begin{array}{l}\text { Hadapan Allah SWT -> } \\
\text { Kualitas Audit }\end{array}\end{array}$ & $-0,016$ & $-0,049$ & 0,152 & 0,106 & 0,916 \\
\hline
\end{tabular}

Sumber: Data diolah menggunakan SmartPLS, 2019

1. Pengaruh Integritas Terhadap Kualitas Audit

Nilai t-statistik yang diperoleh pada variabel integritas terhadap kualitas audit sebesar 3,803 dimana lebih besar dari t-kritis sebesar 2,02. Dengan demikian, dapat disimpulkan bahwa $\mathrm{H}_{0}$ ditolak dan $\mathrm{H}_{1}$ diterima. Hasil tersebut menunjukkan bahwa terdapat pengaruh signifikan antara variabel integritas dengan variabel kualitas audit. Adapun korelasi antar variabel integritas terhadap kualitas audit sebesar nilai path coefisiennya ialah 0,566 yang menunjukkan bahwa variabel berpengaruh signifikan.

Hasil pengujian hipotesis ini sejalan dengan kode etik profesi IAPI tentang Prinsip Integritas bahwa seorang auditor muslim yang memiliki sikap memadai dalam jujur dan kebenaran seharusnya akan mempengaruhi tingkat kualitas audit. Hal ini dibuktikan dengan hasil jawaban dari responden yang dapat dilihat dari grafik dibawah ini sebagai berikut:

Grafik 1. Indikator X1.d, Y1.a, Y1.c

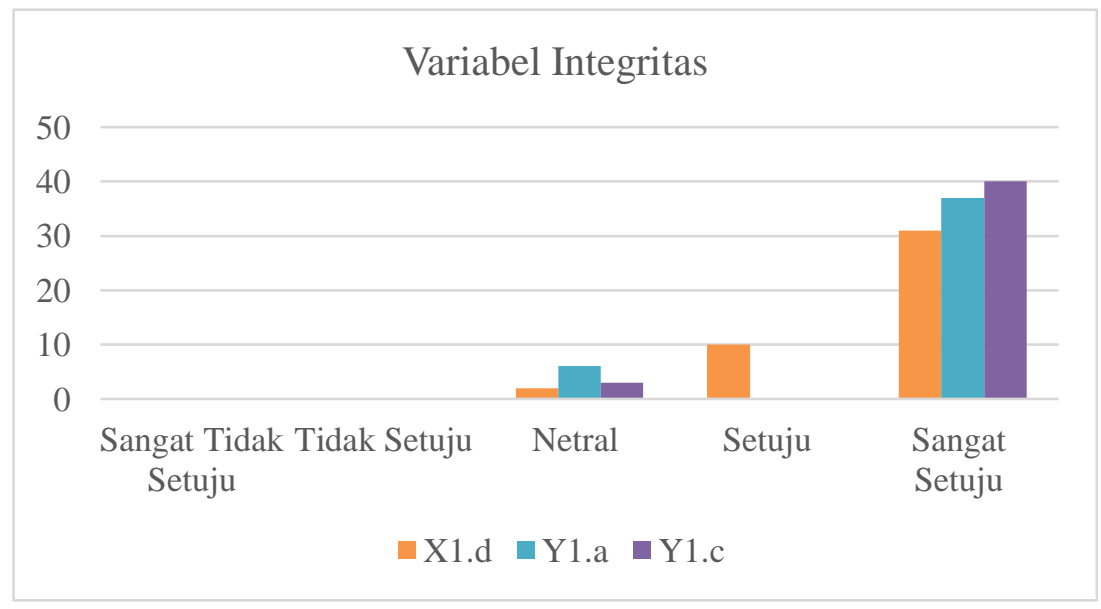

Sumber:Data diolah menggunakan Excel,2019 
Berdasarkan grafik 1 menunjukkan bahwa mayoritas dari jawaban responden adalah setuju dan sangat setuju. Jawaban tersebut membuktikan bahwa responden setuju bahwa semakin tinggi integritas seorang auditor muslim, maka audit yang dilakukan akan terhindar dari bentuk-bentuk kecurangan yang kemungkinan dapat terjadi, sehingga hal ini dapat meningkatkan kualitas audit.

Hasil penelitian ini didukung oleh teori pendukung Mabruri dan Winarna (2010:10) bahwa jika seorang auditor memiliki integritas yang baik maka dapat meningkatkan kualitas audit. Adapun hasil penelitian Ayuningtyas (2012) yang menunjukkan bahwa integritas memberikan pengaruh signifikan terhadap kualitas audit, demikian juga penelitian yang dilakukan Sari (2011) yang menunjukan bahwa integritas memberikan pengaruh yang signifikan terhadap kualitas audit.

Berdasarakan Kode Etik Profesi Akuntan Publik, seksi 100 menyatakan bahwa integritas sebagai berikut : "Integritas adalah unsur karakter yang mendasar bagi pengakuan profesional, integritas merupakan kualitas yang menjadikan timbulnya kepercayaan masyarakat dan tatanan nilai tertinggi bagi anggota profesi dalam menguji semua keputusan. Integritas memfokuskan seorang auditor bertindak jujur, tegas tanpa memihak kepada pihak lain".

Auditor muslim dalam bekerja diharuskan untuk bersikap benar, adil, dan jujur dalam pelaksanaan prinsip integritas ini. Auditor muslim harus dapat berterus terang sehingga laporan yang dibaca oleh pemakai informasi berisi fakta-fakta yang ada. Dari sinilah auditor muslim dapat meningkatkan kualitas auditnya.

\section{Pengaruh Khalifah dan Ikhlas Terhadap Kualitas Audit}

Nilai t-statistik yang diperoleh pada variabel khalifah dan ikhlas terhadap kualitas audit sebesar 0,855 dimana lebih kecil dari t-kritis sebesar 2,02. Dengan demikian, dapat disimpulkan bahwa $\mathrm{H}_{0}$ diterima dan $\mathrm{H}_{1}$ ditolak. Hal ini menunjukkan bahwa variabel khalifah dan ikhlas tidak berpengaruh signifikan terhadap kualitas audit. Adapun korelasi antara variabel khalifah dan ikhlas terhadap kualitas audit sebesar nilai path coefisienya ialah 0,138. Jadi dapat disimpulkan bahwa khalifah dan ikhlas berpengaruh tidak signifikan terhadap kualitas audit.

Hal tersebut menunjukkan bahwa khalifah dan ikhlas bukan merupakan faktor yang kuat dalam mempengaruhi kualitas audit. Hal ini dibuktikan dengan grafik 2 : 
Grafik 2. Masa Kerja

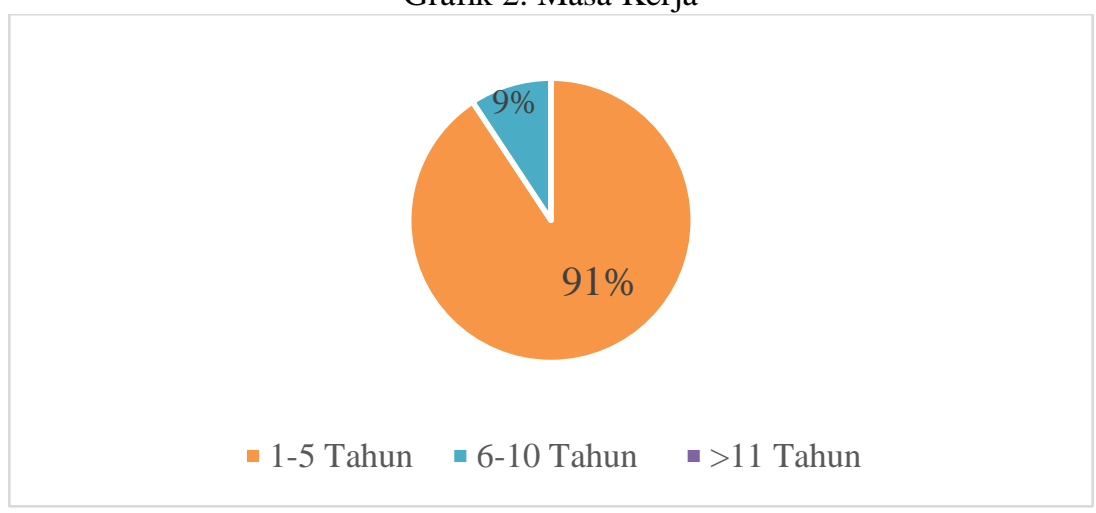

Sumber: Data diolah, 2019

Berdasarkan grafik 2 menunjukkan mayoritas responden dari penelitian ini adalah auditor yang memiliki masa kerja 1-5 tahun. Indikator pengukur dari penelitian ini adalah pengabdian terhadap profesi, kemandirian dan keyakinan profesi. Variabel khalifah dan ikhlas ini tidak berpengaruh terhadap kualitas audit dikarenakan pada masa kerja kurang dari 5 tahun maka auditor kurang memiliki pengabdian terhadap profesi yang dijalaninya. Selain itu auditor dianggap belum memiliki sikap kemandirian saat melaksanakan tugas audit. Dan yang terakhir yaitu ketika masa kerja auditor memiliki masa kerja yang kurang dari 5 tahun maka auditor tersebut belum sepenuhnya yakin terhadap profesi yang sedang dijalankannya saat ini.

Penelitian ini didukung oleh penelitian yang dilakukan oleh (Elen, 2013) menunjukkan bahwa variabel profeisonalisme tidak memiliki pengaruh signifikan terhadap kualitas audit. Hal tersebut terjadi dimungkinkan responden memberikan respon terhadap pengisian kuesioner dengan jawaban yang tidak positif, terutama pada jenjang manajer kebawah, menurut respon yang diberikan bahwa untuk mendapatkan kualitas audit yang maksimal tidak harus memiliki sikap profesional yang memadai.

3. Pengaruh Ketakwaan dan Takut pada Allah SWT Terhadap Kualitas Audit

Nilai t-statistik yang diperoleh pada variabel ketakwaan dan takut pada Allah SWT terhadap kualitas audit sebesar 0,369 dimana lebih kecil dari t-kritis sebesar 2,02. Dengan demikian, dapat disimpulkan bahwa $\mathrm{H}_{0}$ diterima dan $\mathrm{H}_{1}$ ditolak. Hal ini menunjukkan bahwa variabel ketakwaan dan takut pada Allah SWT tidak berpengaruh signifikan terhadap kualitas audit. Adapun korelasi antara variabel ketakwaan dan takut pada Allah SWT terhadap kualitas audit sebesar nilai path coefisienya ialah -0,079. Jadi dapat disimpulkan bahwa ketakwaan dan takut pada Allah SWT tidak berpengaruh signifikan terhadap kualitas audit. 
Menurut (Harahap, 2002) takwa adalah sikap ketakutan kepada Allah baik dalam keadaan tersembunyi maupun terang-terangan sebagai salah satu cara untuk melindungi diri dari akibat negatif dan perilaku yang bertentangan dari syariat khususnya dalam hal yang berkaitan dengan perilaku terhadap penggunaan kekayaan atau transaksi yang cenderung pada kedzaliman dan hal lain yang tidak sesuai dengan syariat. Seseorang akan membentengi dirinya dengan kejujuran ketika dia merasa apa yang dilakukannya adalah benar.

Hasil penelitian ini mendukung penelitian yang dilakukan oleh Wardani (2013) yang menjelaskan bahwa sikap kehati-hatian tidak berpengaruh terhadap kualitas audit. Variabel ketakwaan dan takut pada Allah SWT diukur menggunakan dua indikator yang pertama yaitu kehatihatian atas informasi yang diperoleh dan yang kedua adalah penggunaan dan pengungkapan atas informasi yang diterima. Dalam penelitian ini variabel ketakwaan dan takut pada Allah SWT tidak berpengaruh terhadap kualitas audit dikarenakan banyaknya auditor junior yang mengisi kuesioner dalam penelitian ini. Auditor junior dianggap kurang mampu untuk menggunakan dan mengungkapkan infomasi dengan baik. Hal tersebut dapat dilihat dari grafik dibawah ini :

Grafik 3. Jenjang Jabatan

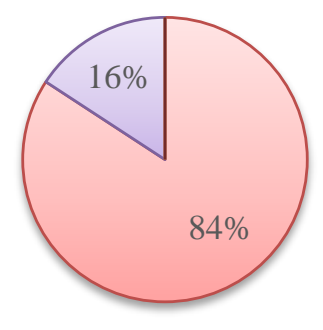

\section{$\square$ Auditor Junior $\quad \square$ Auditor Senior $\quad \square$ Manajer $\quad \square$ Partner}

Sumber: Data diolah, 2019

4. Pengaruh Kebenaran dan Bekerja Secara Sempurna Terhadap Kualitas Audit

Nilai t-statistik yang diperoleh pada variabel kebenaran dan bekerja secara sempurna terhadap kualitas audit sebesar 0,494 dimana lebih kecil dari tkritis sebesar 2,02. Dengan demikian, dapat disimpulkan bahwa $\mathrm{H}_{0}$ diterima dan $\mathrm{H}_{1}$ ditolak. Hal ini menunjukkan bahwa variabel kebenaran dan bekerja secara sempurna tidak berpengaruh signifikan terhadap kualitas audit. Adapun korelasi antara variabel kebenaran dan bekerja secara sempurna terhadap kualitas audit sebesar path coefisienya ialah 0,101. Jadi dapat disimpulkan bahwa kebenaran dan bekerja secara sempurna tidak berpengaruh signifikan terhadap kualitas audit. 
Akuntan dan auditor tidak harus membatasi dirinya dengan hanya melakukan pekerjaan-pekerjaan profesi dan jabatannya tetapi juga harus bertujuan untuk mencari dan menegakkan kebenaran dan kesempurnaan tugas profesinya dengan melaksanakan semua tugas yang dibebankan kepadanya dengan sebaik-baik dan sesempurna mungkin (Harahap, 2002). Hal ini tidak akan bisa direalisasikan terkecuali melalui kualifikasi akademik, pengalaman praktik, dan pemahaman serta pengalaman keagamaan yang diramu dalam pelaksanaan tugas profesinya. Kompetensi diperoleh melalui pendidikan dan pengalaman.

Dalam penelitian ini variabel kebenaran dan bekerja secara sempurna tidak berpengaruh terhadap kualitas audit dimungkinkan karena mayoritas responden dari penelitian ini adalah auditor junior. Auditor junior dianggap kurang memiliki kompetensi dalam bidang audit sehingga tidak dapat menghasilkan kualitas audit yang baik. Auditor junior atau anggota seyogyanya tidak menggambarkan dirinya memiliki keandalan atau pengalaman yang tidak mereka miliki. Hal ini dibuktikan dengan hasil demografi responden, didapat hasil demografi jenjang jabatan yang dapat kita lihat melalui grafik 3 .

Ketika melakukan proses audit, auditor membutuhkan pengetahuan dan pengalaman yang baik karena dengan kedua hal tersebut, auditor menjadi lebih mampu memahami kondisi keuangan dan laporan keuangan kliennya.

Seorang auditor yang memiliki pengetahuan dan terus menerus mengikuti pelatihan, mengikuti pendidikan formal terutama pendidikan profesi untuk meningkatkan kompetensinya maka akan meningkatkan kualitas audit yang dimilikinnya, seperti dalam teori atribusi yang menyatakan bahwa perilaku seseorang yang ditentukan oleh kekuatan internal (Internal Forces) yaitu kemampuan atau usaha yang dilakukan, sehingga apabila seseorang yang mempunyai kemampuan yang didukung oleh kompetensi yang kuat akan memunculkan perilaku seorang auditor yang akan mempengaruhi kualitas audit.

5. Pengaruh Manusia Bertanggung Jawab Di hadapan Allah SWT Terhadap Kualitas

Nilai t-statistik yang diperoleh pada variabel kebenaran dan bekerja secara sempurna terhadap kualitas audit sebesar 0,106 dimana lebih kecil dari tkritis sebesar 2,02. Dengan demikian, dapat disimpulkan bahwa $\mathrm{H}_{0}$ diterima dan $\mathrm{H}_{1}$ ditolak. Hal ini menunjukkan bahwa variabel bertanggung jawab di hadapan Allah SWT tidak berpengaruh signifikan terhadap kualitas audit. Adapun korelasi antara variabel bertanggung jawab di hadapan Allah SWT terhadap kualitas audit sebesar nilai path coefisiennya ialah -0,016. Jadi dapat disimpulkan bahwa bertanggung jawab di hadapan Allah SWT tidak berpengaruh signifikan terhadap kualitas audit.

Auditor harus meyakini bahwa Allah selalu mengamati semua perilakunya dan dia akan mempertanggung jawabkan semua tingkah lakunya kepada Allah nanti di hari akhir baik tingkah laku yang ataupun tingkah laku yang buruk. Laporan audit adalah hal yang penting, bukan hanya untuk 
kepentingan tertentu namun utuk kepentingan masyarakat agar meniadakan praktik-praktik yang menyimpang. Semua pihak harus menciptakan suatu iklim dan kesadaran agar aktivitas auditor dapat dibentengi dengan kode etiknya. Kesadaran auditor menekankan pentingnya membangun sikap percaya. Auditor dapat secara mandiri dan bertanggung jawab untuk mengambil keputusan dan melaksanakan tindakan berdasarkan kode etik profesinya.

Audit menuntut keahlian dan profesionalisme yang tinggi, salah satunya dipengaruhi oleh faktor pengalaman (Tjun et al., 2012). Pengalaman seseorang ditunjukkan dengan lamanya seseorang melakukan pekerjaan untuk mendapatkan ilmu yang sebenarnya bisa didapatkan selain dari pendidikan formal. Semakin lama masa kerja dan pengalaman yang dimiliki oleh auditor maka akan semakin baik dalam meningkatkan kualitas audit yang dihasilkan. Auditor yang memiliki pengalaman yang tinggi akan memiliki keunggulan dibeberapa hal diantaranya : (1) mendeteksi kesalahan, (2) memahami kesalahan, (3) mencari penyebab munculnya kesalahan (Sukriah et al., 2009).

Penelitian ini mendukung penelitian yang dilakukan oleh (Elen, 2013) menunjukkan hasil yang tidak signifikan terhadap kualitas audit. Hal ini menggambarkan bahwa sikap bertanggung jawab di hadapan Allah SWT tidak berpengaruh terhadap kualitas audit. Hal ini dibuktikan dengan melihat responden yang mengisi keusioner dalam penelitian ini.

Grafik 4. Masa Kerja

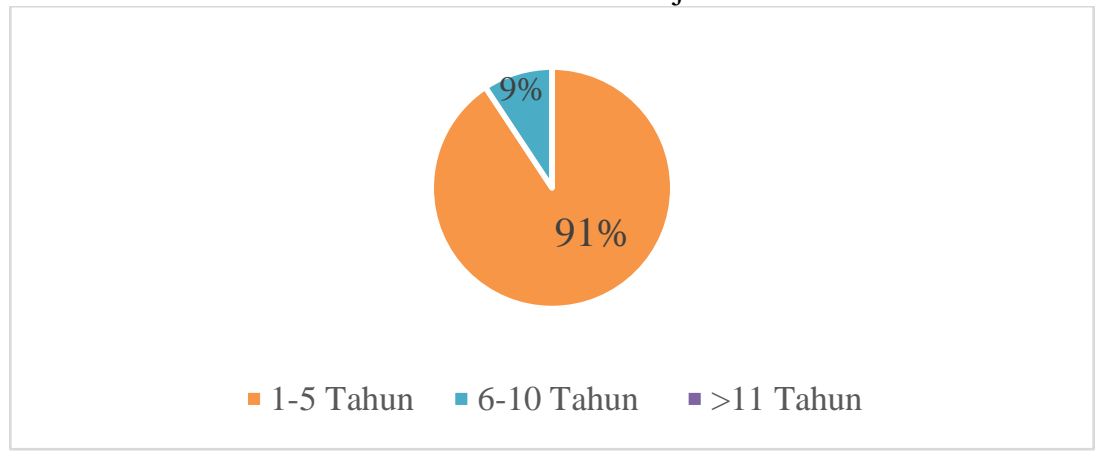

Sumber: Data diolah, 2019

Mayoritas responden yang mengisi penelitian ini adalah auditor yang memiliki masa kerja 1 sampai 5 tahun. Pada penelitian ini variabel kualitas audit diukur dengan dua indikator. Yang pertama yaitu bebas dari benturan kepentingan. Dan yang kedua adalah pengungkapan kondisi sesuai fakta. Dengan masa kerja auditor yang kurang dari 5 tahun maka auditor dianggap kurang memiliki pengalaman yang cukup dalam mendeteksi kesalahan dan mengungkapkannya sesuai dengan fakta yang telah terjadi. 
6. Uji Secara Simultan

Tabel 7. Hasil Nilai R Square

\begin{tabular}{cc}
\hline Variabel & R Square \\
\hline Kualitas Audit & 0,415 \\
\hline
\end{tabular}

Sumber: Data diolah menggunakan SmartPLS, 2019

Berdasarkan tabel 7 diatas dapat diketahui bahwa hasil R Square sebesar 0,415. Hal ini menunjukkan bahwa kualitas audit dapat diprediksi oleh integritas, khalifah dan ikhlas, ketakwaan dan takut pada Allah SWT, kebenaran dan bekerja secara sempurna dan bertanggung jawab di hadapan Allah SWT sebesar 0,415. Sedangkan sisanya sebesar 0,585 dijelaskan oleh variabel eksogen lain diluar model yang diteliti.

\section{KESIMPULAN DAN SARAN}

\subsection{KESIMPULAN}

Dari variabel Interitas, Khalifah dan Ikhlas, Ketakwaan dan Takut pada Allah SWT, Kebenaran dan bekerja secara sempurna dan bertanggung jawab di Hadapa Allah SWT yang di uji dalam penelitian ini hanya variabel Integritas yang memiliki pengaruh signifikan terhadap kualitas audit.

Hasil pengujian integritas ini sejalan dengan kode etik profesi IAPI tentang Prinsip Integritas bahwa seorang auditor muslim yang memiliki sikap memadai dalam jujur dan kebenaran seharusnya akan mempengaruhi tingkat kualitas audit. Sementara variabel Khalifah dan Ikhlas tidak berpengaruh signifikan terhadap variabel Kualitas Audit dikarenakan auditor muslim belum mempunyai pengabdian yang tinggi terhadap profesi, kemandirian, dan keyakinan. Variabel Ketakwaan dan Takut pada Allah SWT tidak berpengaruh signifikan terhadap kualitas audit, dikarenakan sikap takwa dan takut pada Allah SWT tidak berhubungan secara langsung terhadap kegiatan muamalah perindividu. Variabel Kebenaran dan Bekerja Secara Sempurna berpengaruh tidak signifikan terhadap kualitas audit dikarenakan penelitian ini mayoritas responden adalah audit junior, sehingga masih banyak kompetensi yang belum dimiliki. Variabel Bertanggung Jawab di Hadapan Allah SWT berpengaruh tidak signifikan terhadap kualitas audit dikarenakan dengan mayoritas responden pada penelitian ini adalah audit junior, sehingga rasa kehati-hatian dalam pengungkapan informasi yang mereka miliki masih rendah.

Dengan demikian dari kelima variabel yang diuji dalam penelitian ini hanya variabel interitas yang memiliki pengaruh signifikan terhadap kualitas audit menurut persepsi auditor muslim di wilayah Jakarta dan Depok. 


\subsection{SARAN}

Penelitian ini diharapkan memberikan manfaat bagi pihak-pihak yang berkepentingan dalam hal peningkatan kualitas audit. Berikut saran yang dapat penulis berikan untuk perbaikan dimasa yang akan datang :

1. Bagi Kantor Akuntan Publik dapat digunakan untuk memperbaiki praktik dalam melakukan audit dengan meningkatkan dan memperhatikan kualitas hasil kerja yang dilakukannya dengan menggunakan variabel yang sudah diteliti yang mempunyai pengaruh terhadap kualitas audit yaitu integritas. Karena dalam penelitian ini integritas mempunyai pengaruh terhadap kualitas audit paling dominan.

2. Bagi peneliti selanjutnya, dapat mempertimbangkan untuk menggunakan objek penelitian yang lebih luas dengan ruang lingkup beberapa provinsi atau kabupaten/kota.

\section{DAFTAR PUSTAKA}

Agoes, S. (2017). Auditing (Edisi 5). Jakarta: Salemba Empat.

Elen, T. (2013). Pengaruh Akuntabilita, Kompetensi, Profesionalisne, Integritas, dan Objektivitas, Akuntan Publik Terhadap Kualitas Audit Dengan Independensi Sebagai Variabel Moderating (Studi Empiris Pada Beberapa KAP Afliasi Asing dan KAP Non Afliasi Asing di Jakarta. Media Riset Akuntansi, Auditing \& Informasi, 13.

Harahap, S. S. (2002). Auditing Dalam Perspektif Islam. (N. Faizah, A. Suntoro, Y. Aminah, \& Linda, Eds.), Pustaka Quantum (Cetakan 1). Jakarta, Indonesia: PT. Pustaka Quantum.

Khairunisa, A. A., \& Hanny Yustrianthe, R. (2015). Kajian Empiris FaktorFaktor Yang Memengaruhi Kualitas Audit. Jurnal Ilmiah Wahana Akuntansi, 10(1), 1-23.

Kompas. (2010). Akuntan Publik di Duga Terlibat. Retrieved October 31, 2018 , https://regional.kompas.com/read/2010/05/18/21371744/Akuntan.Publ ik.Diduga.Terlibat

Ludigdo, U. (2006). Strukturasi Praktik Etika di Kantor Akuntan Publik: Sebuah Studi Interpretif. Simposiun Nasional Akuntansi, 6, 23-26.

Luthans, F. (2005). Organizational Behavior. New York.

Masluhih, H., Masyhad, \& Hidayati, K. (2016). Pemaknaan Kode Etik Auditor Eksternal Dalam Perspektif Syariah, Equity, 3(2), 272-289.

Mulyadi. (2002). Auditing (Edisi Keenam). Jakarta: Salemba Empat. 
Noviyanti, S. (2008). Skeptisme Profesional Auditor dalam Mendeteksi Kecurangan. Jurnal Akuntansi Dan Keuangan Indonesia, 5(I), 102125 .

Prabowo, A. (2018). Siaran Pers OJK Kenakan SanksiTerhadap Akuntan Publik Dan Kantor Akuntan Publik Auditor PT. Sunprima Nusantara Pembiayaan. Retrieved October 23, 2018, from https://www.ojk.go.id/id/berita-dan-kegiatan/siaran-pers/Pages/SiaranPers-OJK-Kenakan-Sanksi-terhadap-Akuntan-Publik-dan-KantorAkuntan-Publik-Auditor-PT-Sunprima-Nusantara-Pembiayaan.aspx

Sugiyono. (2010). Metode Penelitian Pendidikan Pendekatan Kuantitatif, Kualitatif, dan R\&D. Bandung: Alfabeta.

Sukriah, I., Akram, \& Inapty, B. A. (2009). Pengaruh Pengalaman Kerja, Independensi, Obyektifitas, Integritas dan Kompetensi Terhadap Kualitas Hasil Pemeriksaan. Sna, 1-38.

Tjun, L. T., Marpaung, E. I., \& Setiawan, S. (2012). Pengaruh Kompetensi dan Independensi Auditor Terhadap Kualitas Audit. Jurnal Akuntansi, $4(1), 33-56$.

Tuanakotta, TM (2017). Audit Kontemporer. Jakarta: Salemba Empat .

Yamin, S., \& Kurniawan, H. (2011). Partial Least Square Path Modeling (Edisi 4). Jakarta: Salemba Infotek. 